\title{
The potentials of technology complementarity to address energy poverty in refugee hosting landscapes in Uganda
}

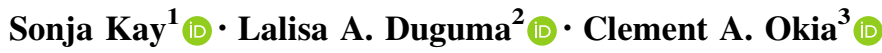 \\ ${ }^{1}$ Agroscope, Research Division Agroecology and Environment, Research Group Agricultural Landscape and Biodiversity, Zurich, Switzerland \\ ${ }^{2}$ World Agroforestry (ICRAF) and ASB Partnership for the Tropical Forest Margins, Landscape and Governance Theme, Nairobi, Kenya \\ ${ }^{3}$ World Agroforestry (ICRAF), Uganda Country Office Representative, C/O National Forestry Resources Research Institute, Kampala, Uganda
}

Received: 21 August 2020/Revised: 27 November 2020/Accepted: 14 December 2020/Published online: 9 January 2021

(C) The Author(s) 2021

\begin{abstract}
The continued influx of refugees into Uganda confronts people and hosting landscapes with severe challenges. Vast volumes of biomass resources are required for energy and building materials. Consequently, woodlands have come under pressure as the key source within refugee-receiving regions. This raises the question of how to simultaneously achieve a higher standard of living and energy autonomy for the population while reducing primary resource demand and safeguarding nature. We propose that nature-based and/or technological adaptions can ameliorate this dramatic and deteriorating situation. We thus evaluated the impact of: (i) building autonomy by growing biomass resources on scale via approaches such as agroforestry and ii) enhancing energy efficiency through use of improved cook stoves (ICS) and switching toward renewable energy sources. Focusing on four Ugandan districts, we analyzed the energy and land demand of households and districts in three scenarios. Our results show all districts running into shortages of biomass resources and cultivable land and two districts already reaching their limits. An efficient use of woodfuel combined with solar energy could reduce primary energy demand by up to
\end{abstract}

Supplementary Information The online version contains supplementary material available at https://doi.org/10.1007/s40974020-00204-z.

Sonja Kay

sonja.kay@agroscope.admin.ch

Lalisa A. Duguma

1.duguma@cgiar.org

Clement A. Okia

c.okia@cgiar.org
$37 \%$. The remaining wood demand could be realized by agroforestry systems thereby ensuring household energy autonomy and access to reliable energy sources. We recommend combining energy efficiency measures and technology to reduce firewood demand with agroforestry solutions to satisfy the remaining necessities. Both are needed to reduce the essistential pressure on woodlands and increase the energy autonomy of refugee-hosting landscapes while respecting stakeholder needs.

Keywords Agroforestry · Energy demand · Biomass potential $\cdot$ Renewable energies $\cdot$ Nature-based solutions

\section{Background}

According to the United Nations Refugee Agency (UNHCR) Uganda is the largest refugee-hosting country in Africa hosting some 1,425,040 refugees (URRP 2020), mostly from South Sudan, the Democratic of the Congo (DRC), and Burundi. Current projections assume an increase in the number of refugees in future years (UNHCR 2016).

In 2016, the Ugandan government, with the financial and technical support of the UN, UNHCR and World Bank, released a Refugee and Host Population Empowerment (ReHoPE) strategy. This allows refugees to work, establish businesses, and have access to social services; land for agricultural production is also allocated to them. The main aim of the strategy is the economic and social integration of refugees and empowerment of and support to host communities (UNHCR 2016). Unfortunately, related to this development, the share of people living in poverty in 
Uganda increased from $17.2 \%$ in $2012 / 13$ to $21.4 \%$ in 2018/19 (UBOS 2017a, 2019).

Family and household empowerment relates closely to access to energy (González-Eguino 2015). The United Nations Agenda for Sustainable Development (UN 2015) have Sustainable Development Goals include SDG 7 affordable and clean energy, which calls for access to affordable, reliable, sustainable, and modern energy for all and the absence of which is known as "energy poverty" (UNDP 2000). The International Energy Agency (IEA) defines access to modern energy as [...] household access to a minimum level of electricity; [...] to safer and more sustainable cooking and heating fuels and stoves than traditional biomass stoves; access that enables productive economic activity. In sub-Saharan Africa, 590 million people are currently without access to electricity, and 780 million people or $78 \%$ rely on solid biomass for cooking (IEA 2017).

According to González-Eguino (2015), energy poverty has three dimensions: (i) technological, (ii) physical, and (iii) economic. The technological dimension refers to access to modern, affordable, reliable, high quality, safe, and environmentally benign energy services (everything except traditional biomass use) and the choice between equivalent options (UNDP 2000). This covers energy facilities and knowledge on how to use and maintain them. The physical dimension addresses the (minimum) energy requirements - the amount of energy a person or a household needs to serve their basic needs. Finally, the economic dimension quantifies the percentage of household income spent on energy. According to IEA (2017), households spending more than $10 \%$ of their income or their household members' working hours on energy are considered as energy poor. For example, in 2012/13 the Ugandan population spent around $15.0 \%$ of their income on rent, fuel, and electricity (UBOS 2017b). In 2016/2017, this rose to $16.4 \%$ (UBOS 2019).

Energy use and fuel choice are affected by external and internal factors (Van Der Kroon et al. 2013). In theory, when the socio-economic status of households rises, they climb the "energy ladder" and switch between fuels. The transformation process runs gradually over time from socalled primitive fuels (firewood, agricultural, and animal waste) to transition fuels (charcoal, kerosene, and coal) to advanced fuels (LPG, electricity, and biofuels). Several authors have expressed doubts about this theory. Yu-Ting Lee (2013) found that charcoal stoves were still in use even in upper-income households for preparation of traditional foods (e.g., matooke in Uganda), and Munro and Bartlett (2019) highlighted the common use of multiple types of energy, calling it "energy bricolage". Yet, there is no doubt that households with low income rely almost entirely on primitive fuels used inefficiently e.g., three-stone-stoves
(Yu-Ting Lee 2013; Bekele et al. 2015). Lack of access to modern energies causes negative impacts on human wellbeing. Several studies, e.g., de la Sota et al. (2018) and Jeuland and Pattanayak (2012), highlighted the air pollution of primitive fuel burners and their negative repercussions for human health.

There are also deleterious effects on the economy and environment. Waste gases are a significant source of greenhouse gas emissions (Duguma et al. 2014), and a high level of biomass consumption is linked to other environmental problems such as forest and land degradation and water pollution (Jagger and Shively 2014). In Uganda, forests are degrading due to population growth and firewood consumption. Most of the districts are experiencing a growing demand for woodfuel as accessible wood available is diminishing (MWE 2017). This situation will be further aggravated by population growth and refugees moving in.

Growing trees on agricultural fields, known as agroforestry, can simultaneously provide food, fodder, and a reliable source for firewood. Iiyama et al. (2014) and Faße et al. (2014) pointed out that, if widely adopted, agroforestry could provide sustainable woodfuel while reducing pressure on forest land and increase the autonomy and independence of farmers. Moreover, agroforestry systems fit neatly into the above-described energy transition process: trees from agroforestry can serve as sources of woodfuel in their establishment phase and also provide food and fodder for humans and animals plus construction materials as they develop. In the specific context of refugee settlements, the advantages of agroforestry become even more valuable. Refugees need to start from scratch, their households have little or no income and, thus, mainly rely on primitive fuels such as woodfuel collected from surrounding vegetation (FAO and UNHCR 2017). After they settle and become more established, their rising energy demand for production communication, and other purposes could be provided by renewable energies. Solar facilities are particularly promising in rural areas of sub-Saharan Africa.

This study investigated possibilities for refugee-hosting communities to acquire a sufficient, reliable, and autonomous energy supply while reducing the overall pressure on natural resources. We investigated nature-based and technology options, focusing on (i) building additional biomass resources on scale through agroforestry and (ii) implementing technological solutions that enhance energy efficiency such as improved cookstoves (ICS) and switching to renewable energy sources such as solar panels or biogas. These were economically and ecologically evaluated at household and district levels.

The study is divided into three parts. First, an overview of the current situation of the energy market and energy demand in Uganda is presented. Second, we zoomed into 
the refugee-hosting regions and evaluated the potential for building biomass resources. Finally, we investigated the economic and ecological impact of technology complementarity at household level and upscaled the ecological effects to district level.

\section{Energy supply and demand in Uganda}

\subsection{Current energy supply}

Large parts of sub-Saharan Africa, especially rural areas, are not connected to the national electricity grid and have no access to (off-grid) electricity and only a low availability of fuels (IEA 2017). Renewable energies are therefore highly promising. They are sustainable, can perform off-grid, and are available in small-scale installations with low economic, technical, and learning input required. They are increasingly promoted by national governments (e.g., MEMD 2013; Müller et al. 2020) and international organizations (United Nations 2015). Still, few plants are installed or remain in function.

According to the Ugandan Ministry of Energy and Mineral Development (MEMD 2014), 78.6\% of the national electricity production is generated by hydropower. The balance is provided by petroleum-based thermal and biomass co-generation sources. Energy production of solar panels and biogas plants is not mentioned in the national energy balance. Several regulations and strategies to support renewable energies are in place, e.g., Uganda's Rural Electrification Strategy and Plan 2013-2022, National Development Plan II, Uganda's Vision 2040 (Uganda Domestic Biogas Program, Uganda National Alliance for Clean Cookstoves, Renewable Energy Policy, and Biomass Energy Strategy). The aim is to electrify $30 \%$ of Ugandan households up to 2030 and provide a substantial part from renewable energies. Studies estimate that this will cost between $\$ 0.63$ billion and $\$ 1.24$ billion (Basudde 2020). Uganda also aims to increase efficiency of energy use (de la Rue du Can et al. 2018).

At present, wood energy is the most crucial energy source in Uganda, serving the cooking purposes of $94 \%$ of the population (UBOS 2017a). Roughly two-thirds is estimated to come from firewood and one-third from charcoal. The firewood is mostly collected in bush or forest sites, only $26 \%$ comes from plantations; an estimated $9 \%$ is bought. The price of woodfuel increased by up to $10 \%$ between 2005 and 2010 (UBOS 2017b).

The biomass is mostly burned in traditional three-stonestoves with a very low efficiency rate. Improved cookstoves (ICS) have higher fuel efficiency and reduce indoor air pollution yet are not well established in the market. According to the Global Alliance for Clean Cookstoves
(GVEP International 2012), only 6\% or rural households and $14 \%$ of peri-urban households own an ICS in Uganda. However, more positively, in Bidibidi refugee settlement in Uganda in 2017, $43 \%$ of households were using ICS (FAO and UNHCR 2017).

Solar energy is used for lighting purposes in $20.7 \%$ of rural households in Uganda (UBOS 2017a). Depending on the system, it can provide electricity or hot water. So-called Solar Home Systems (SHS) produce electricity with solar panels and have batteries to store the energy. They are a stand-alone solution (no connection to the grid). Little technical knowledge is needed to maintain the system. These systems allow for prosumerism or prosumers, a combination of producer and consumer of renewable energies (Khan 2019). In comparison, solar water heating systems are less common; even so, they are cheaper than SHS and very easy to install and handle. The outcome is hot water, which can be used for cooking and reduces (but does not replace) the fuel input.

Around 7600 biogas plants are working in Uganda. Biogas plants digest manure, urine, and other biogenic residues to generate gas, which can be used for cooking and lighting. The facility works continuously. Small-scale plants have a capacity of 4 to $6 \mathrm{~m}^{3}$ and can produce between 1.5 to $1.8 \mathrm{~m}^{3}$ gas (KENDBIP 2014; Kamp and Bermúdez Forn 2016). Nonetheless, the requirements for the required continuous input are high (the manure of three head of cattle that are penned, confined). Investigations by Lwiza et al. (2017) showed that, in the long term, changes in the number of livestock or technical problems at the installations are key obstacles for biogas users. In the refugee-hosting region under consideration here, livestock are relatively scant, which disqualifies biogas as an option.

\subsection{Energy demand}

The UN Secretary-General's Advisory Group on Energy and Climate Change (AGECC 2010) distinguishes between consecutive levels of energy demand: the basic human needs, the productive uses, and the modern society needs.

- The minimum energy demand is referred to as basic human needs (BHN) and covers fuel for cooking and heating and electricity for lighting, communication, health, and education.

- The second level, productive uses (PU), incorporates the Basic Human Needs and adds the demand for commercial and agricultural production as well as transportation. This includes e.g., fertilization, irrigation, mining, and industrial processes.

- The third level, the modern society needs, satisfies all of the above as well as energy for domestic appliances, cooling and heating, and private transportation. 
A literature research was conducted to evaluate the energy demand of the BHN and PU levels. As this study was conducted among refugees and host communities with poor livelihood states, we did not consider modern society needs.

As presented in Table 1, the IEA sets a threshold of 250 $\mathrm{kWh}$ per household in rural areas and $500 \mathrm{kWh}$ in urban households, which translates to $50-100 \mathrm{kWh}$ per capita per year $\left(\mathrm{kWh} \mathrm{cap}^{-1} \mathrm{yr}^{-1}\right.$ ) (IEA 2017). In addition to this electricity threshold, the AGECC (2010) recommends 50-100 $\mathrm{kg}_{\mathrm{oe}} \mathrm{cap}^{-1} \mathrm{yr}^{-1}$ for modern fuels to fulfill the BHN. In sum, around 700-1300 kWh cap $\mathrm{kr}^{-1}$ is needed. The energy demand will increase if PU is optimized for efficiency. To reflect this González-Eguino (2015) quantified the BHN of up to $5 \mathrm{GJ}$ cap $^{-1} \mathrm{yr}^{-1}$ ( 1388 $\mathrm{kWh}$ cap $^{-1} \mathrm{yr}^{-1} ; 100 \mathrm{kWh}$ electricity \& 1501 gasoline) and the PU to around $10 \mathrm{GJ} \operatorname{cap}^{-1} \mathrm{yr}^{-1}$ ( $=2,777 \mathrm{kWh}$ cap $^{-1} \mathrm{yr}^{-1} ; 750 \mathrm{kWh}$ electricity and 2201 gasoline). In comparison, modern societies tend to use $25 \mathrm{GJ}^{\mathrm{cap}^{-1}}$ $\mathrm{yr}^{-1}$; the USA currently needs around $150 \mathrm{GJ} \mathrm{cap}^{-1} \mathrm{yr}^{-1}$.

Another way to assess peoples' minimum energy needs is to quantify the required energy services. For example, each person needs two hot meals per day (Agea et al. 2010), five hours of light, and access to communication tools. This results in an energy demand of $10 \mathrm{MJ}^{\mathrm{cap}}{ }^{-1}$ $\mathrm{yr}^{-1}$ or $1013 \mathrm{kWh} \mathrm{cap}^{-1} \mathrm{yr}^{-1}$ for cooking and less than 50 $\mathrm{kWh}$ cap $^{-1} \mathrm{yr}^{-1}$ for electricity. In totality, energy services of between $1063 \mathrm{kWh} \mathrm{cap}^{-1} \mathrm{yr}^{-1}$ and $1388 \mathrm{kWh} \mathrm{cap}^{-1}$ $\mathrm{yr}^{-1}$ should at least be available to satisfy the BHN.

\section{Methods}

\subsection{Case study region}

The study was conducted in north-western Uganda in the districts of Adjumani, Arua, Moyo, and Yumbe. According to UNHCR (URRP 2020), these districts host around $44.5 \%$ of all refugees. The area shares a border with South
Sudan and is in the semi-moist savannah agroecological zone. Currently around 1,750,000 citizens and 955,000 refugees live in the $10,459 \mathrm{~km}^{2}$ area (see Fig. 1). The focus of the study was on the refugee settlements of Imvepi and Rhino Camp and host communities of Odupi and Uriama in Arua district.

In Arua district, in Imvepi and Rhino Camp refugee settlements and Odupi and Uriama host communities, a semi-quantitative questionnaire was conducted in 2017 to evaluate the needs and priorities of inhabitants to restock woody biomass. This was part of "Sustainable use of natural resources and energy in the refugee context in Uganda", a project undertaken by GIZ Uganda, Uganda's National Forestry Authority and Arua District Local Government (Forest Office), UK Aid (DFID) and World Agroforestry. Detailed information on the questionnaire and its outcomes in Duguma et al. (2019).

In total, 280 households (121 Imvepi, 119 Rhino Camp, 25 Odupi, and 15 Uriama) were posed questions in the different local languages on issues such as: (i) how to improve the state of their surrounding landscape, (ii) which tree species are prioritized and used for which purposes (construction, firewood, etc.), and (iii) how many trees of which species would a household need to establish to meet those purposes?

The main reasons mentioned to re-establish woody biomass were need for construction materials, edible parts, firewood, and shade. Windbreaks, income, medicine, or rainfall improvements were little mentioned as reasons for restocking biomass. The households stated that they intended to plant trees on or around their land and homesteads either scattered, as woodlots or on the boundaries of fields. Some mentioned planting on degraded land. For further details, see Duguma et al. (2019). The following analysis concentrates on firewood production and therefore focuses only on tree species and numbers mentioned for woodfuel purposes.

Table 1 Minimum energy thresholds of one person for basic human needs and productive use

\begin{tabular}{|c|c|c|c|c|c|}
\hline Demand & Description & $\begin{array}{l}\text { Electricity } \\
{\left[\mathrm{kWh}^{-1} \mathrm{yr}^{-1}\right]}\end{array}$ & $\begin{array}{l}\text { Fuel }[\mathrm{kWh} \\
\left.\operatorname{cap}^{-1} \mathrm{yr}^{-1}\right]\end{array}$ & $\begin{array}{l}\text { Total }[\mathrm{kWh} \\
\left.\text { cap }^{-1} \mathrm{yr}^{-1}\right]\end{array}$ & Source \\
\hline \multirow[t]{3}{*}{$\begin{array}{l}\text { Basic human } \\
\text { needs }\end{array}$} & \multirow{3}{*}{$\begin{array}{l}\text { Electricity for lightning, } \\
\text { communication, health, education } \\
\text { plus fuels for cooking and heating }\end{array}$} & $50-100$ & $600-1200$ & $700-1300$ & $\begin{array}{l}\text { (AGECC 2010; IEA } \\
\text { 2017) }\end{array}$ \\
\hline & & 100 & 1288 & 1388 & $\begin{array}{l}\text { (González-Eguino } \\
\text { 2015) }\end{array}$ \\
\hline & & 50 & 1013 & 1063 & (Agea et al. 2010) \\
\hline Productive Use & $\begin{array}{l}\text { Basic Human Needs plus commercial } \\
\text { and agricultural production, } \\
\text { transportation }\end{array}$ & 750 & 2027 & 2777 & $\begin{array}{l}\text { (González-Eguino } \\
\text { 2015) }\end{array}$ \\
\hline
\end{tabular}




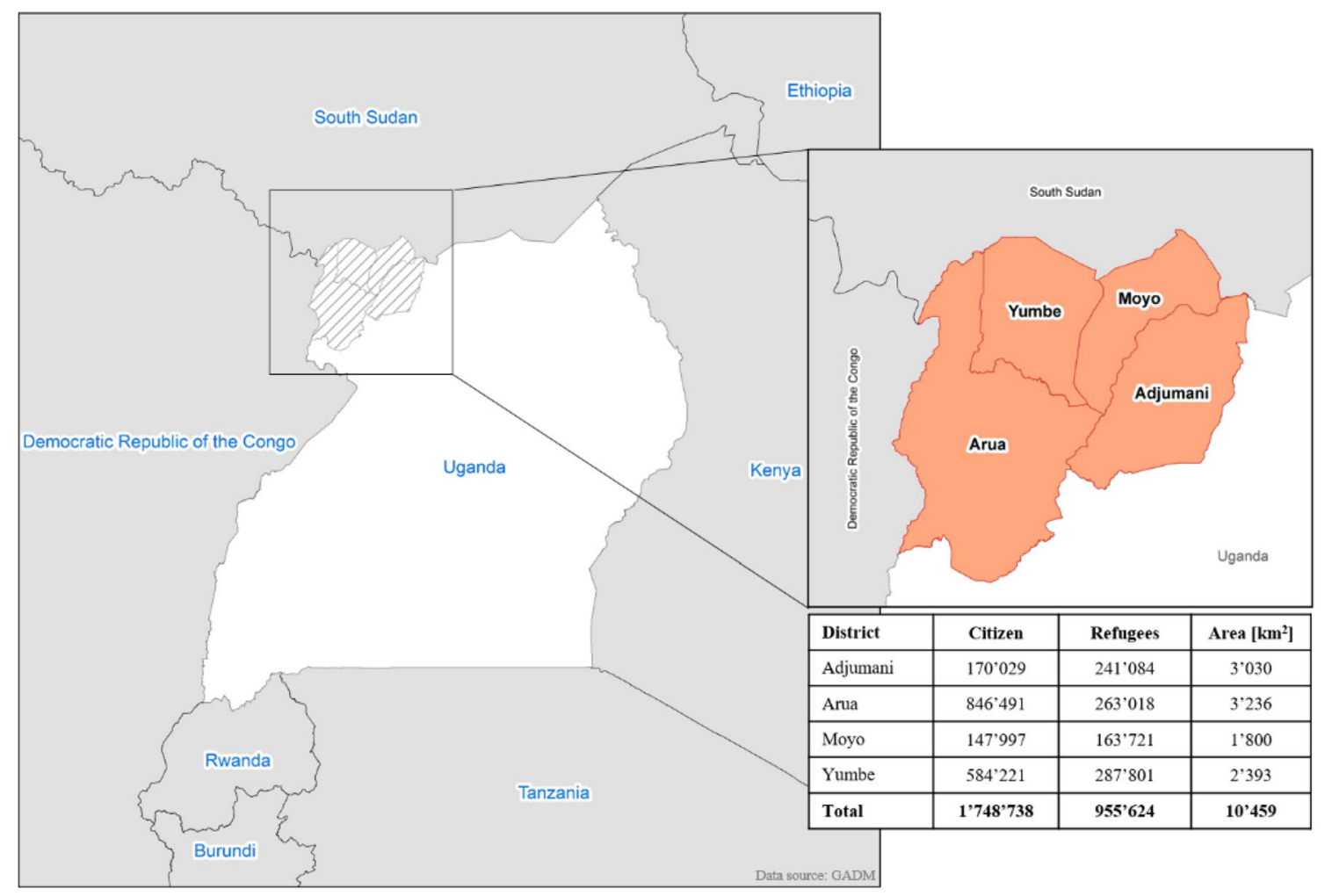

Fig. 1 Map and numbers of inhabitants of the case study region located in north-western Uganda

\subsection{Estimating the woody biomass resource development potential}

A list of tree species favored for firewood and charcoal uses was aggregated based on the questionnaires. After that, fuelwood tree species were ranked according to the number of times mentioned. Ranking was done for the total and for firewood and charcoal preferences.

Key tree parameters such as stature (tree, shrub), wood density (in $\mathrm{kg} \mathrm{m}^{-3}$ ), calorific value (in $\mathrm{kJ} \mathrm{g}^{-1}$ ), and mean annual increment (MAE) (in $\mathrm{t} \mathrm{ha}^{-1} \mathrm{yr}^{-1}$ ) were collected. All information was gathered from the Agroforestree Database (Orwa et al. 2009) in combination with literature data (Ugalde et al. 2001; Tabuti et al. 2003; Erakhrumen 2009; Kisekka 2010; Musinguzi et al. 2012; Balogun et al. 2014; Duruaku et al. 2016; FAO and UNHCR 2017).

Yield assessment was based on data from Uganda's National Biomass Studies (MWLE 1992, 2002), which in1992 found an average harvestable biomass potential of $0.78 \mathrm{t} \mathrm{ha}^{-1}$ air-dry weight tree biomass and $0.55 \mathrm{t} \mathrm{ha}^{-1}$ shrub biomass over all land cover classes for the northwestern region "Arua", the semi-moist lowland savannah area into which Adjumani, Moyo, and Yumbe districts also fall. For this agroecological zone, the national biomass studies found significant peaks for biomass and tree distribution in subsistence farmland areas in small diameter classes $\left(5 \mathrm{~cm}\right.$ : 170 trees $\mathrm{ha}^{-1}$ and $1 \mathrm{t} \mathrm{ha}^{-1} ; 10 \mathrm{~cm}$ : 300 trees ha ${ }^{-1}$ and $5 \mathrm{tha}^{-1}$ ). Diameters over $30 \mathrm{~cm}$ were rare. According to their measurements, the MAE was $4.2 \mathrm{t}$ $\mathrm{ha}^{-1} \mathrm{yr}^{-1}$ in woodlands, $0.3 \mathrm{tha}^{-1} \mathrm{yr}^{-1}$ in bushland, $1.2 \mathrm{t}$ $\mathrm{ha}^{-1} \mathrm{yr}^{-1}$ in grassland, and $1.7 \mathrm{t} \mathrm{ha}^{-1} \mathrm{yr}^{-1}$ in substantial farmland. FAO and UNHCR (2017) investigated tree density and biomass stock around Ugandan refugee settlements for the land use classes "closed woodlands", "open woodlands", "bushlands", and "cultivated land". They found, on average, between 367 trees ha ${ }^{-1}$ and 1209 trees $\mathrm{ha}^{-1}$ and a biomass stock of $2.02 \mathrm{t} \mathrm{ha}^{-1}$ to $56.96 \mathrm{t}$ $\mathrm{ha}^{-1}$. In cultivated land, they listed $367( \pm 1,112)$ trees $\mathrm{ha}^{-1}$ with an aboveground biomass stock of around $12.49 \mathrm{t}$ $\mathrm{ha}^{-1}$. They estimated the MAE of woodland plantations to be between $20-26 \mathrm{~m}^{3} \mathrm{ha}^{-1}$ and $18-23.4 \mathrm{t} \mathrm{ha}^{-1} \mathrm{yr}^{-1}$.

The energy valuation was separately done for each tree species and based on the MAE measurements multiplied by the calorific value of the timber. The results were aggregated into a Tree-Mix, which was used for the subsequent calculations.

\subsection{Estimating the costs associated with energy supply technologies}

The study focused on three different scenarios covering two conditions for BHN and PU, respectively. Scenarios were calculated using a typical refugee household of 5 persons as an estimate. Energy demand was analyzed for a 
Basic, Improved, and Renewable Scenario. Each scenario was investigated under market conditions for commercial firewood consumption and for self-supply by establishing agroforestry plots. An overview of the three scenarios is in Table 2.

Three-stone-stoves were assessed in the Basic scenario, using an efficiency rate of $15 \%$ and investment cost of $\$ 10$ (IEA 2017). In the Improved scenario, ICSs were used, with a presumed efficiency rate of $31 \%$ and $\$ 29$ investment cost (IEA 2017). In the Renewable scenario, ICSs were also used while a $6 \mathrm{~W}$ solar panel fulfilled the electricity. The investment cost for the solar system was $\$ 80$.

An average Ugandan household consumed between 1.53-3.9 $\mathrm{t}$ firewood $\mathrm{yr}^{-1}$ related to energy costs of $\$ 0-260 \mathrm{yr}^{-1}$ (Tabuti et al. 2003; Agea et al. 2010; GVEP International 2012; MEMD 2016). The market price for firewood was $\$ 6-16 \mathrm{t}^{-1}$ as at 2020 market conditions.

FAO and UNHCR (2017) mapped the landscape around the refugee settlements and found, on average, 367 trees ha $^{-1}$ in cultivated land, 394 trees ha ${ }^{-1}$ in bushland, 647 trees $\mathrm{ha}^{-1}$ in open woodlands, and 1209 trees ha- 1 in closed woodlands. The (re)establishment of wooded plots, particularly the raising and planting of seedlings, costs around $\$ 1$ tree $^{-1}$ in sub-Saharan Africa (Duguma et al. 2019). Based on these assumptions, establishment of agroforestry in cultivated land would cost $\$ 367 \mathrm{ha}^{-1}$.

The analyses were conducted using $\mathrm{R}$ ( $\mathrm{R}$ Development Core Team 2016). R packages ggplot2 (Wickham 2016) and tidyverse (Wickham 2017) were used to create the figures and QGIS (QGIS Development Team 2015) for the map.

\section{Results}

\subsection{Potential for increasing biomass resources}

Asking the refugees which trees species, they would like to plant for fuelwood; enumerators collected a list of 460 trees of 56 different species. This list was aggregated according to the number of times a species was mentioned and ranked. Table 3 shows the list. The most mentioned species were Tectona grandis, Eucalyptus spps, Senna siamea, Azadirachta indica, and Combretum molle.

The preferred tree species had a calorific value that ranged between $5167 \mathrm{kWh} \mathrm{t}^{-1}$ for the wood of Terminalia ivorensis and $7400 \mathrm{kWh} \mathrm{t}^{-1}$ for the wood of Combretum molle. The average was $5954 \mathrm{kWh} \mathrm{t}^{-1}$. For detailled information see supplementary material.

Based on these findings, tree species were then ranked to include woodfuel suitability. As shown in Fig. 2, Senna siamea was both preferred and suitable as firewood, while Tectona grandis was mentioned by refugees but does not have a high calorific value.

Combretum molle has a high calorific value, is highly plantable, but refugees do not or far less consider it a fuelwood species because they might want to sell it as poles or for timber largely due to its high market value as timber than as firewood. While some of the least calorific species such as Acacia hockii are taken into account. The biggest difference is shown for Eucalyptus spp., meaning it is very popular by refugees but the calorific value is quite low.

This results in different timber quantities needed to provide the same energy output. For example, while $2.8 \mathrm{t}$ of Combretum molle could fulfill the basic demands, nearly $4 \mathrm{t}$ of Terminalia ivorensis were needed for the same amount of energy.

\subsection{Comparison of nature-based and technological alternatives}

\subsubsection{Energy and land demand}

To fulfill the BHN, a net energy input of 20,000-46,000 $\mathrm{kWh}$ household ${ }^{-1} \mathrm{yr}^{-1}$ was required, depending on the

Table 2 List of evaluated scenarios

\begin{tabular}{|c|c|}
\hline Basic human needs (BHN) & Productive uses (PU) \\
\hline I. Basic scenario (served by three-stone-stoves) & I. Basic scenario (served by three-stone-stoves) \\
\hline a. Market (firewood consumption) & a. Market (firewood consumption) \\
\hline b. Agroforestry (firewood self-supply) & b. Agroforestry (firewood self-supply) \\
\hline II. Improved scenario (served by ICS) & II. Improved scenario (served by ICS) \\
\hline a. Market (firewood consumption) & a. Market (firewood consumption) \\
\hline b. Agroforestry (firewood self-supply) & b. Agroforestry (firewood self-supply) \\
\hline III. Renewable scenario (served by ICS and solar panels) & III. Renewable scenario (served by ICS and solar panels) \\
\hline a. Market (firewood consumption) & a. Market (firewood consumption) \\
\hline b. Agroforestry (firewood self-supply) & b. Agroforestry (firewood self-supply) \\
\hline
\end{tabular}


Table 3 Most mentioned tree species that refugees stated that they wanted to plant (source: Duguma et al. 2019) and their calorific value

\begin{tabular}{|c|c|c|c|c|c|c|}
\hline \multirow[t]{2}{*}{$\mathrm{Nr}$} & \multirow[t]{2}{*}{ Species } & \multicolumn{2}{|c|}{ Refugee settlements } & \multicolumn{2}{|c|}{ Hosting communities } & \multirow{2}{*}{$\begin{array}{l}\text { Calorific value } \\
{\left[\mathrm{kWh} \mathrm{t}^{-1}\right]}\end{array}$} \\
\hline & & Imvepi & Rhino camp & Odupi & Uriama & \\
\hline 1 & Tectona grandis & 58 & 44 & 3 & 7 & 5625 \\
\hline 2 & Eucalyptus spps & 51 & 30 & 6 & 6 & 5333 \\
\hline 3 & Senna siamea & 32 & 25 & 8 & 7 & 6222 \\
\hline 4 & Azadirachta indica & 15 & 35 & 3 & 3 & 6306 \\
\hline 5 & Combretum molle & 12 & 19 & 6 & 3 & 7400 \\
\hline 6 & Acacia hockii & 8 & 10 & 7 & 3 & 5333 \\
\hline 7 & Mangifera indica & 18 & 5 & 1 & 3 & 5515 \\
\hline 8 & Melia azadirachta & 7 & 9 & 7 & 1 & 5931 \\
\hline \multirow[t]{2}{*}{9} & Terminalia ivorensis & 7 & 11 & & & 5167 \\
\hline & Total number & 208 & 178 & 41 & 33 & \\
\hline
\end{tabular}

Fig. 2 Ranks of refugees' most mentioned tree species for planting (red squares)and the species' woodfuel suitability (blue rhombi). The difference between the two is shown by the gray bars

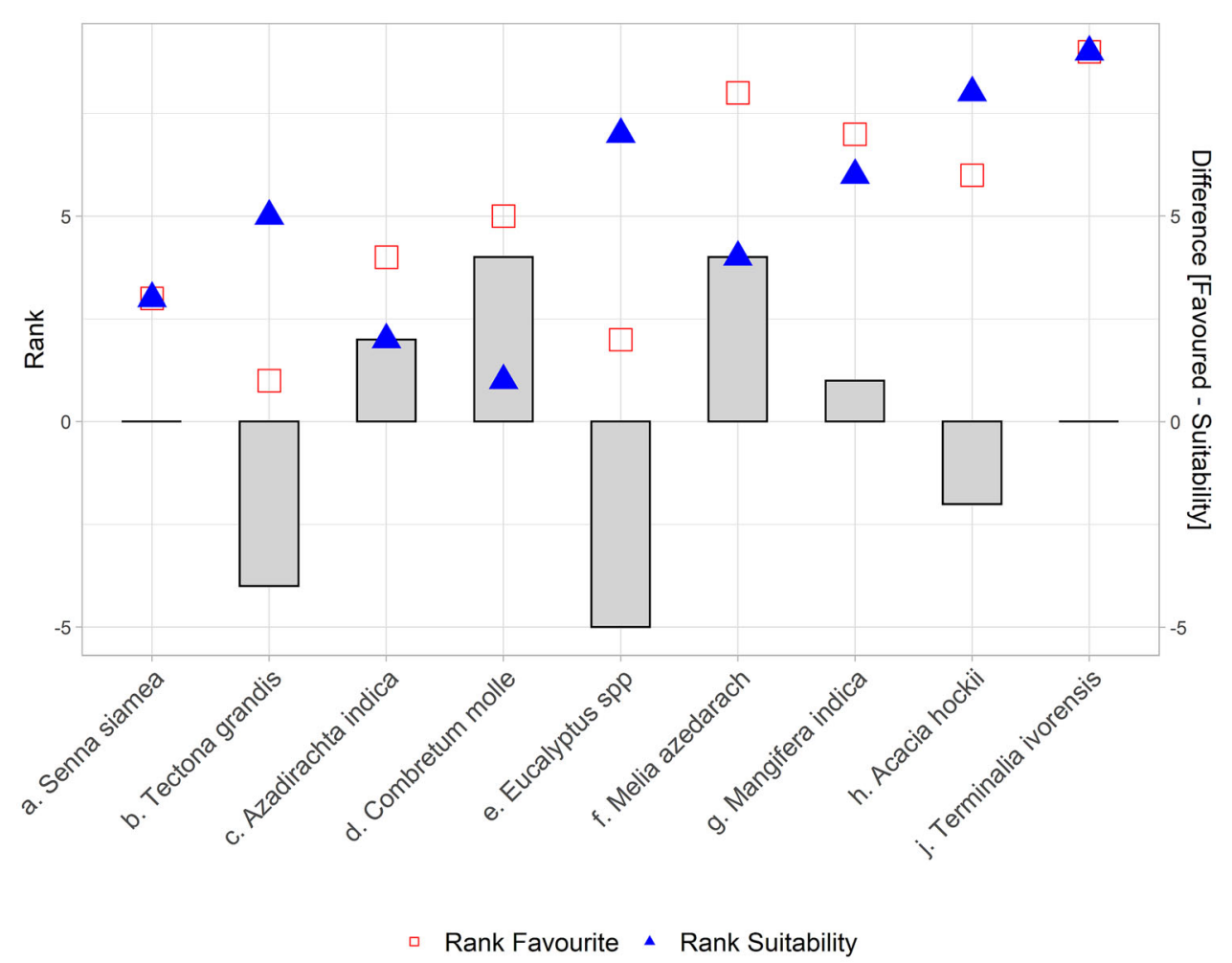

cooking technology used. This rose to $92,000 \mathrm{kWh}$ household ${ }^{-1} \mathrm{yr}^{-1}$ for PU.

If three-stone-stoves are the only cooking method deployed, this translated into a wood fuel usage of between 6.25 and $8.95 \mathrm{t}^{\text {household }}{ }^{-1}$ to fulfill the BHN depending on the tree species used. This would require between 3.68-5.27 ha household ${ }^{-1}$ of subsistence farmland. Wood used could be reduced to $2.81 \mathrm{t}^{\text {household }}{ }^{-1}$ and $4.02 \mathrm{t}$ household $^{-1}$, respectively, if ICS and renewable energies were used instead. This translates to a land demand of 1.65 to 2.37 ha household ${ }^{-1}$.

If the level of PU was fulfilled by wood only in the Basic scenario, the demand would rise to $12.51-17.92 \mathrm{t}$ household $^{-1}$ (with an equivalent land demand of 7.36-10.54 ha household ${ }^{-1}$ ). This could be reduced to 6.05-8.67 $\mathrm{t}_{\text {household }}{ }^{-1}$ by using ICS. It could be further reduced to $4.42-6.33 \mathrm{t}^{\text {household }}{ }^{-1}$ and land demand of 2.6-3.72 ha household ${ }^{-1}$ by using ICS and solar panels as combined sources.

\subsubsection{Economic assessment at a household level}

The household costs for basic annual energy consumption were between $\$ 66.46$ (ICS, market) and \$351.22 (threestone-stove plus agroforestry) considering over five years. If the amortization time were increased to 20 years, the 
annual costs were reduced to $\$ 43.69$ (ICS, agroforestry) and $\$ 125.87$ (three-stone-stove, market). Already within the first year, the additional costs for ICS were refunded by reduced woodfuel expenses. The renewable alternative became cheaper after four years in comparison to the traditional three-stone-stoves. The high investment costs for the renewable alternative was balanced out by savings on fuel purchases after 19 years, after which it became the scenario with the cheapest energy costs (see Fig. 3).

The establishment of agroforestry plots to produce fuel and thus replace the expense of buying fuel in the market had the biggest economic impact. Although the investment costs were high in the beginning, they were refunded after 15 years. This was true for both for BHN and PU (see Fig. 3).

\subsubsection{Impacts and implications at a district level}

These results provide insight into how much land is needed to meet the energy requirement demand of inhabitants and refugees. They suggest that it would require $25,733 \mathrm{~km}^{2}$ of subsistence farmland to fulfill the BHN with the traditional way three-stone-cooking method (Basic scenario). Utilizing energy efficient stoves would reduce the required area to $12,451 \mathrm{~km}^{2}$. Using renewable energy as well, 11,554 $\mathrm{km}^{2}$ land is still needed. This would be $110-246 \%$ of available land in the four districts. To fulfill the PU demand, an area between $18,184 \mathrm{~km}^{2}$ and $51,486 \mathrm{~km}^{2}$ would be needed, $173-492 \%$ of the total available land in the four districts.
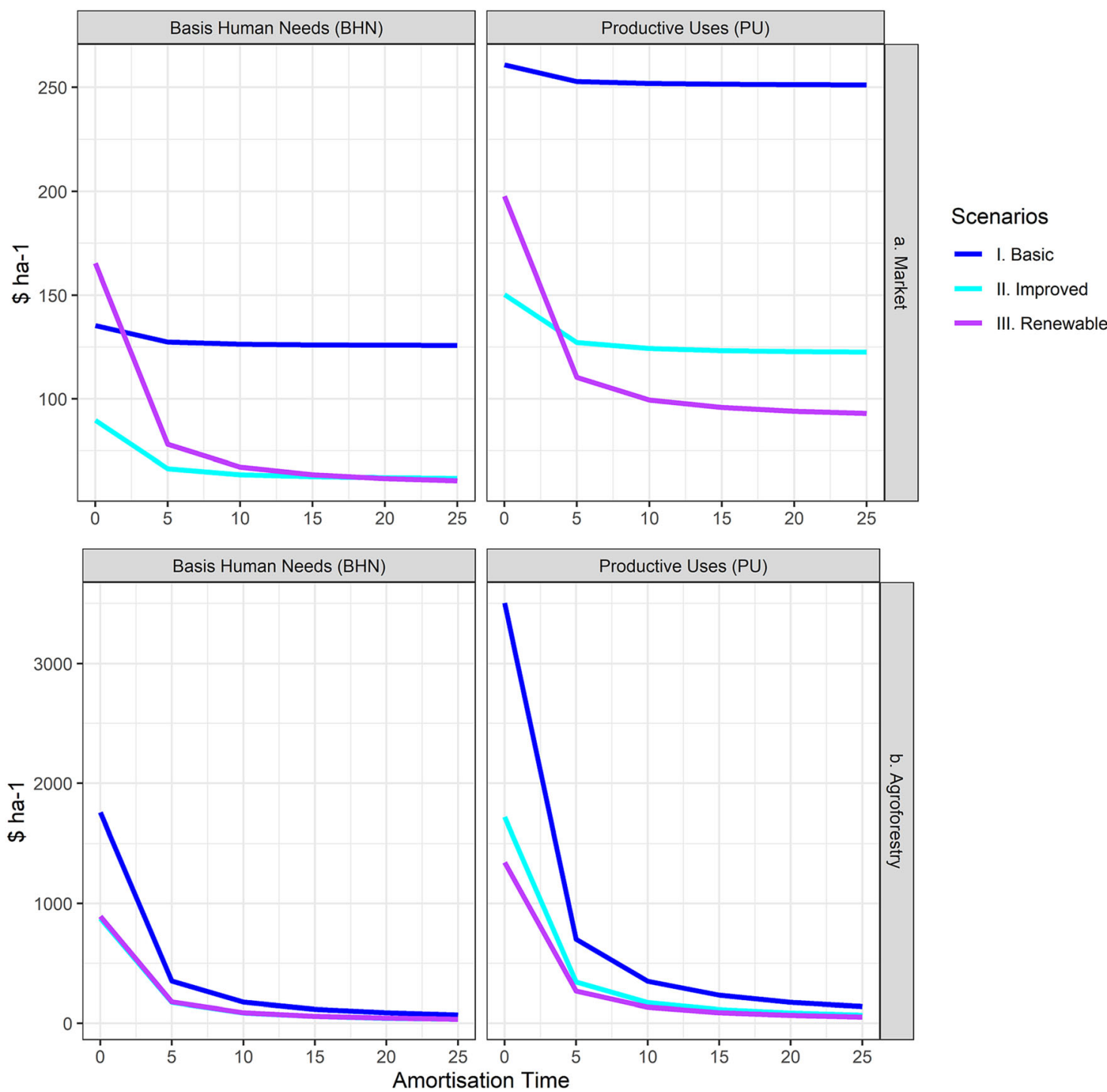

Fig. 3 Economic evaluation of the assessment of the scenarios at different amortisation times $(0,5,10,15,20$, and 25 years) for Basic Human Needs (BHN) and Productive Uses (PU) under a. market conditions and b. agroforestry in cultivated land [Blue: Basic scenario, light blue: Improved scenario, pink: Renewable scenario] 
Focusing at district level, especially in Arua and Yumbe districts, the demand for biomass and the land to produce it was in all scenarios higher than the total district area. While Adjumani and Moyo district can still meet the basic demand, they will have problems to fulfill the productive demands (see Fig. 4).

\section{Discussion}

This study investigated two pathways for communities to generate energy supply: (i) building energy by growing biomass resources at scale with agroforestry and (ii) enhancing energy efficiency by using technological alternatives (e.g., ICS and renewable energy sources like solar). We compared the effects of both ways at household and district levels.

Assessing building biomass resources while taking into account stakeholder needs, households were asked for their favorite tree species for fuelwood. The listed favorite tree species for fuelwood are similar to previous findings of the National Biomass Study (MWLE 1992) for north-western Uganda, which were in Arua district, Combretum spp., Acacia spp., and Grewia for firewood; Combretum spp., Butyrospermum paradoxum, and Terminalia spp. for charcoal production. For Central Uganda, Tabuti et al. (2003) mentioned the importance of Acacia spps, Combretum spp., Milicia excelsa, Lantana camara, Senna siamea, and Senna spectabilis as fuelwood sources. Moreover, the list was consistent with regional tree distribution. FAO and UNHCR (2017) found Acacia hockii as the most dominant tree species followed by Combretum collinum, Grewis mollis, and Combretum fragrans. The only exception was Eucalyptus spps which was not mentioned in previous studies nor measured in the field but favored by refugees for planting.

According to the field measurements (MWLE 2002; FAO and UNHCR 2017), trees in cultivated land had very small diameters (mainly $<20 \mathrm{~cm}$ ) and high tree density per hectare. Small trees and branches were preferred as woodfuel as their collection, and handling is mostly by women (Tabuti et al. 2003) and does not require sophisticated tools or substantial physical strength. However, overall, large and adult trees (diameters $>30 \mathrm{~cm}$ ) have a higher biomass growth compared to young ones as they are increasing in height and in diameter. Hence, they can sustainably provide woodfuel from branches and stems. Moreover, adult trees can provide additional products such as fruits or nuts and vital ecosystem services.

Consequently, management strategies should focus on the long-term establishment and maintenance of trees, especially food and fodder trees. In this context, the establishment of agroforestry can provide multiple benefits: (i) agroforestry plots are mainly located close to settlements, which reduce the collecting time; (ii) annual maintenance of the trees allows for sustainable woodfuel provision, and (iii) adult trees can provide fruits, nuts, and other edible products.

Assessing the potential for technological alternatives, our results showed that in the present circumstances, around $1 \mathrm{t}$ biomass per person per year is needed to fulfill the Basic Human Needs. This demand is higher than that found in previous wood use studies for Uganda. For example, Tabuti et al. (2003) measured a biomass use of 228-341 kg cap ${ }^{-1} \mathrm{yr}^{-1}$, the MEMD (2016) found $137 \mathrm{~kg}_{\mathrm{oe}}$ cap $^{-1} \mathrm{yr}^{-1}$, and Agea et al. (2010) found an annual demand for households of seven members to be $1.53 \mathrm{t}$, which translates to $220 \mathrm{~kg} \mathrm{cap}^{-1} \mathrm{yr}^{-1}$. Most earlier studies tended to focus on cooking energy needs without a proper accounting of other energy needs of households; hence, they generally underestimated demand. Similar results were shown by Duguma et al. (2014) in Ethiopia. Analyzing the energy consumption of farmers, researchers asked for the best possible rate of firewood provision and detected a gap of $65 \%$ between firewood demand and current use.

A similar resource gap between wood demand and supply pertains in the Ugandan biomass market as well. Already the National Biomass Study 2005 highlighted that $73 \%$ of all districts in Uganda will face deficits and will not be able to provide enough biomass (National Forestry Authority 2009).

We showed that efficient use of biomass combined with renewable energies like solar could reduce the biomass demand by up to $37 \%$ in case of the basic needs and up to $50 \%$ for productive use. The remaining wood demand could be realized by agroforestry systems thereby ensuring household energy autonomy and access to reliable energy sources. Similar results were found by Jeuland and Pattanayak (2012); Lascurain et al. (2015), and Kenney and Verploegen (2017). Biomass demand could be further reduced if alternative fuels such as electricity or LPG were popularized and used for cooking.

Likewise, important is the switch from the inefficient three-stone-stove to ICS and on toward clean energy due to health issues. Several studies investigated the negative relation between fuelwood consumption and respiration infection (Jagger and Shively 2014; FDR Ethiopia 2017).

Bekele et al. (2015) summarized energy consumption studies for sub-Saharan Africa and found that the price of energy, income of household, wealth, age of household, sex, size of household, education, and especially owning a refrigerator to be key determinants. In addition, the demand for electricity is rising. While in 2012/13, only 52\% of households in Uganda owned a mobile phone and $2.3 \%$ a fridge, this increased within five years to $74 \%$ and $4.9 \%$, 
Fig. 4 Potential land demand of agroforestry plots to fulfill household energy demand for Basic Human Needs (BHN) and Productive Uses (PU) within the four districts [Blue: Basic scenario, light blue: Improved scenario, pink: Renewable scenario, dotted line: district area]

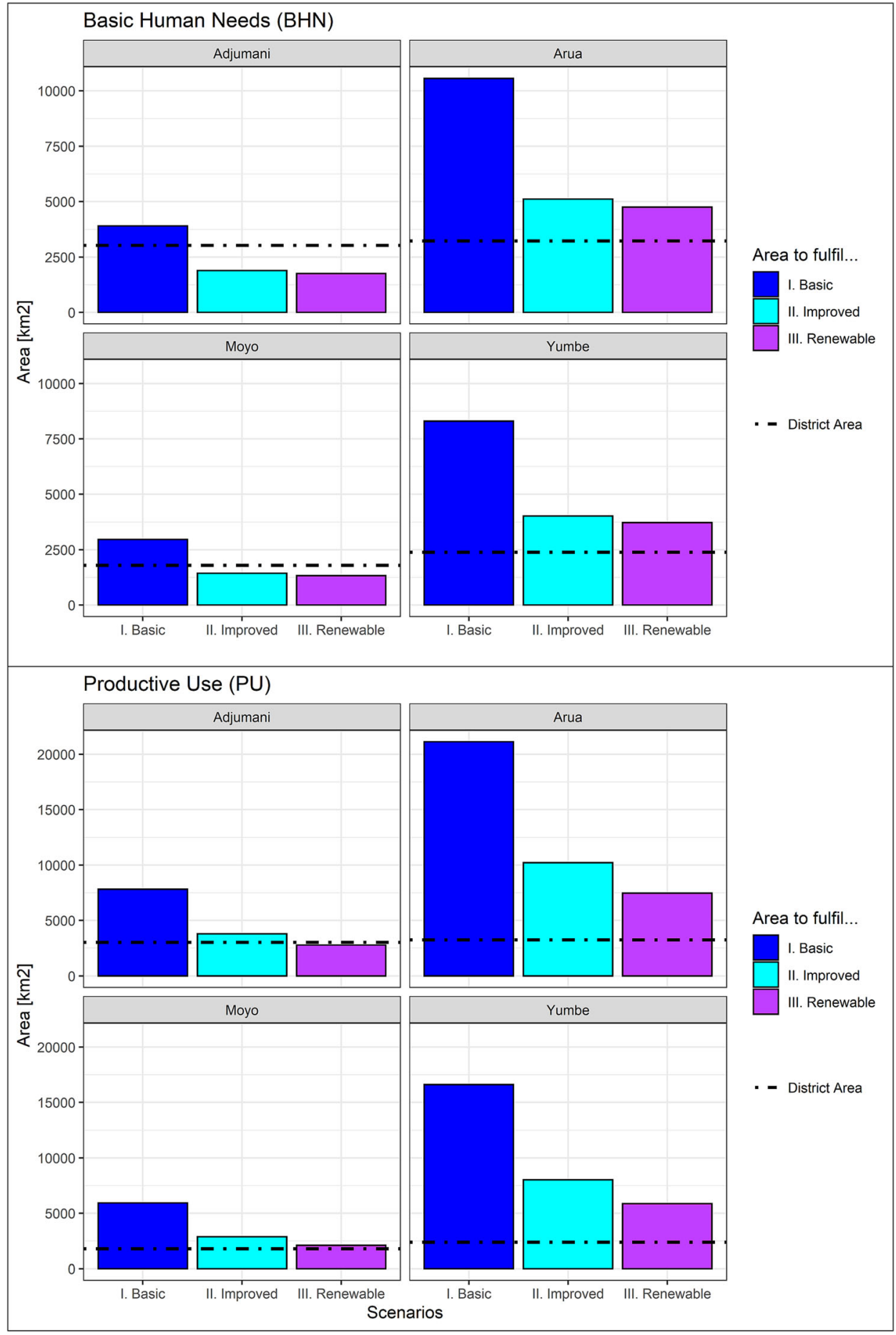

respectively. In the same period, the installation of solar panels increased from $2.2 \%$ to $17.2 \%$ (UBOS 2017a). Hence, renewable enery use is no guarantee for societal benefits (Ikejemba and Schuur 2020). Miller and Ulfstjerne (2020) highlight the need of regionally and culturallyadapted energy production systems respecting stakeholder demands and especially local knowledge.
Regarding economics, we found a long-term reduction in energy costs if efficient facilities were used. At first glance, woodfuel seems the cheapest fuel resource available (Yu-Ting Lee 2013); however, it is also often of low quality and low energy content i.e., poor calorific value. Moreover, households that rely only on firewood have no alternative to switch if prices rise. Thus, the cheap wood resource might end up being even more expensive as 
alternative energy sources are scarce (Foster et al. 2000). To overcome this problem, Agea et al. (2010) recommended encouraging households to grow their own woodlots, and FAO and UNHCR (2017) suggested establishing multiuse agroforestry plots. Our calculations support this recommendation since energy cost is lowest when the fuel is sourced by agroforestry interventions. However, enablers of tree growing need to be put in place before advocating for it. Sufficient planting material is a prerequisite as is a clear understanding of which trees are suitable in the current context of potential tree growing areas.

We focused mainly on the energy supply at the household level. However, refugee settlements are large aggregations of households that would merit thinking about bigger community installations such as biogas plants.

Finally, scaling household level results up to district level, major resource deficits might occur in Arua and Yumbe district as all scenarios have a higher demand for land than the land available. Tackling this requires combining technologies that increase efficiency of fuel use with practices that regenerate more biomass for the community. Our analysis revealed if only tree-based systems are to be used, the tree biomass in the agricultural area has to be increased three fold from $1.7 \mathrm{t} \mathrm{ha}^{-1} \mathrm{yr}^{-1}$ (MWLE 1992, 2002) up to e.g., $5 \mathrm{t} \mathrm{ha}^{-1} \mathrm{yr}^{-1}$.

Promoting the practice of agroforestry needs both policy and technical support. With respect to policy, adoption of the tree growing as viable solution requires that land tenure be clarified and secured. From a technical point of view, a reliable supply of seedlings of the preferred species needs to be in place, and capacity needs to be built on how to manage seedlings to grow to become trees.

\section{Conclusion}

Uganda is $90 \%$ reliant on woodfuel, most of which is harvested from woodlands. Incoming refugees and the establishment of refugee settlements have further increased the resource demand and resulted in environmental pressure on woody vegetation in the landscape. Moreover, the available land area to grow trees for firewood is limited. The four districts investigated here are running into shortages of land and biomass resources; two districts have already reached the limits. A forward-looking plan considering human necessities as well as natural conditions becomes important.

This study found that the energy demand of primary sources (woodfuel) could be reduced by $37 \%$ if efficiency measures such as improved cookstoves and complementary technological options like solar panels were used. The remaining wood demand could be realized by agroforestry systems. Such systems combine tree growing and farming at the field level. Besides being the source of woodfuel, agroforestry is a tree-based solution that serves multiple additional functions such as food, fodder, soil amelioration, and biodiversity enhancement.

Agroforestry, in combination with renewable energies, is therefore a valuable opportunity, especially for rural households. It is also important as an interim solution for the restructuring and transformation of the energy supply: agroforestry systems fit perfectly into the energy transition process, as they serve as energy sources for woodfuel in their establishment phase and later provide construction materials and food and fodder for humans and animals.

Finally, the study highlights that only the combination of nature-based and technological components has the potential to achieve SDG 7 to ensure access to affordable, reliable, sustainable, and modern energy for all. This requires investment in and capacity building on naturebased solutions and investment in the installation of efficient and clean energy technology (improved cookstoves, solar panels). Only this mix will reduce the pressure on woodlands, enhance the environment, and increase the autonomy and independence of Ugandan households, releasing them from energy poverty. Forward-looking joint planning is needed.

Transferring and upscaling our findings to refugeehosting regions in general, we see a huge demand to carry out an overall analysis of the needs combined with (social and environmental) impact assessments. Sectorial concepts that solely focus on efficient and sustainable land use or clean energy consumption are insufficient. Integrative approaches taking the contrasting natural prerequisites, differing economical environments, and various social groups and stakeholder needs into account are required to satisfy economic, ecological, and social needs of refugees and hosting communities.

Acknowledgements We would like to thank the three anonymous reviewers for their constructive comments, which helped to improve an earlier version of the manuscript. The authors acknowledge the support of Cathy Watson for the extensive language edits.

Author contributions SK, LD and CO contributed to the conception and the design of the study. LD and CO organized and administrated the questionnaires. SK performed the statistical analysis in coordination with LD. SK wrote the first draft of the manuscript. LD and CO supplemented and improved the manuscript. All authors contributed to manuscript revision and read and approved the submitted version.

Funding Open Access funding provided by Agroscope. The research was partly supported by forest, trees, and agroforestry of the CGIAR (Consortium Group of International Agricultural Research Centers) research program. All other data sets were obtained within the framework of student graduation theses without external financial support. 
Availability of data and materials Additional data are available in Supplementary Material.

\section{Compliance with ethical standards}

Conflict of interest The authors declare that they have no conflict of interests or competing interests.

Consent to participate This study did not involve any human participant as research subjects.

Consent for publication All participants consented the confidential publication of their contributions in this study.

Ethical approval This study did not involve any human participant as research subjects.

Open Access This article is licensed under a Creative Commons Attribution 4.0 International License, which permits use, sharing, adaptation, distribution and reproduction in any medium or format, as long as you give appropriate credit to the original author(s) and the source, provide a link to the Creative Commons licence, and indicate if changes were made. The images or other third party material in this article are included in the article's Creative Commons licence, unless indicated otherwise in a credit line to the material. If material is not included in the article's Creative Commons licence and your intended use is not permitted by statutory regulation or exceeds the permitted use, you will need to obtain permission directly from the copyright holder. To view a copy of this licence, visit http://creativecommons. org/licenses/by/4.0/

\section{References}

Agea JG, Kirangwa D, Waiswa D, Okia CA (2010) Household firewood consumption and its dynamics in Kalisizo Sub-County, Central Uganda. Ethnobot Leafl 14:841-855

AGECC (2010) Energy for a sustainable future. New York

Balogun AO, Lasode OA, McDonald AG (2014) Thermo-analytical and physico-chemical characterization of woody and non-woody biomass from an agro-ecological zone in Nigeria. BioResources 9:5099-5113. https://doi.org/10.15376/biores.9.3.5099-5113

Basudde P (2020) Promoting the transfer and development of climatesmart energy technologies in Uganda. Encycl World's Biomes. https://doi.org/10.1016/B978-0-12-409548-9.12401-7

Bekele G, Negatu W, Eshete G (2015) Determinants of household energy demand in Ethiopia: the case study of Addis Ababa City. Appl Econ Financ 3:1-14. https://doi.org/10.11114/aef.v3i1. 1193

de la Rue du Can S, Pudleiner D, Pielli K (2018) Energy efficiency as a means to expand energy access: a Uganda roadmap. Energy Policy 120:354-364. https://doi.org/10.1016/j.enpol.2018.05.045

de la Sota C, Lumbreras J, Pérez N et al (2018) Indoor air pollution from biomass cookstoves in rural Senegal. Energy Sustain Dev 43:224-234. https://doi.org/10.1016/j.esd.2018.02.002

Duguma L, Nzyoka J, Okia CA, et al (2019) Restocking woody biomass to reduce social and environmental pressures in refugeehosting landscapes. Perspectives from Northwest Uganda. Work Pap No. https://doi.org/10.5716/WP19032.PDF

Duguma LA, Minang PA, Freeman OE, Hager H (2014) System wide impacts of fuel usage patterns in the Ethiopian highlands: potentials for breaking the negative reinforcing feedback cycles.
Energy Sustain Dev 20:77-85. https://doi.org/10.1016/j.esd. 2014.03.004

Duruaku JI, Ajiwe VIE, Okoye NH, Arinze RU (2016) An Evaluation of the calorific values of the branches and stems of 11 tropical trees. J Sustain Bioenerg Syst 6:44-54

Erakhrumen AA (2009) Energy value as a factor of agroforestry wood species selectivity in Akinyele and Ido local government areas of Oyo State, Nigeria. Biomass Bioenerg 33:1428-1434. https:// doi.org/10.1016/j.biombioe.2009.06.007

FAO, UNHCR (2017) Rapid woodfuel assessment, 2017 baseline for the Bidibidi settlement, Uganda woodfuel

Faße A, Winter E, Grote U (2014) Bioenergy and rural development: the role of agroforestry in a Tanzanian village economy. Ecol Econ 106:155-166

FDR Ethiopia (2017) Ethiopia: demographic and health survey 2016. Federal Democratic Republic of Ethiopia

Foster V, Tre J-P, Wodon Q, Bank W (2000) Energy prices, energy efficiency, and fuel poverty. Washington

González-Eguino M (2015) Energy poverty: an overview. Renew Sustain Energy Rev 47:377-385. https://doi.org/10.1016/j.rser. 2015.03.013

GVEP International (2012) Global alliance for clean cookstoves Uganda market assessment

IEA (2017) Energy access outlook 2017: from poverty to prosperity

Iiyama M, Neufeldt H, Dobie P et al (2014) The potential of agroforestry in the provision of sustainable woodfuel in subSaharan Africa. Curr Opin Environ Sustain 6:138-147. https:// doi.org/10.1016/j.cosust.2013.12.003

Ikejemba ECX, Schuur PC (2020) The empirical failures of attaining the societal benefits of renewable energy development projects in Sub-Saharan Africa. Renew Energy 162:1490-1498. https:// doi.org/10.1016/j.renene.2020.08.052

Jagger P, Shively G (2014) Land use change, fuel use and respiratory health in Uganda. Energy Policy 67:713-726. https://doi.org/10. 1016/j.enpol.2013.11.068.Land

Jeuland MA, Pattanayak SK (2012) Benefits and costs of improved cookstoves: assessing the implications of variability in health, forest and climate impacts. PLoS ONE. https://doi.org/10.1371/ journal.pone. 0030338

Kamp LM, Bermúdez Forn E (2016) Ethiopia's emerging domestic biogas sector: current status, bottlenecks and drivers. Renew Sustain Energy Rev 60:475-488. https://doi.org/10.1016/j.rser. 2016.01.068

KENDBIP (2014) Kenya domestic biogas user survey 2014

Kenney M, Verploegen E (2017) Scaling improved cookstove companies-report from Uganda

Khan I (2019) Drivers, enablers, and barriers to prosumerism in Bangladesh: a sustainable solution to energy poverty? Energy Res Soc Sci 55:82-92. https://doi.org/10.1016/j.erss.2019.04.019

Kisekka JW (2010) Calorific value of selected multipurpose tree species used for woodfuel in Uganda's dryland regions. Makerere University

Lascurain J, Jagoe K, Tilbor C van (2015) Willingness to pay and consumer acceptance assessment for clean cooking in Uganda. Washington

Lwiza F, Mugisha J, Walekhwa PN et al (2017) Dis-adoption of household biogas technologies in central Uganda. Energy Sustain Dev 37:124-132. https://doi.org/10.1016/j.esd.2017.01. 006

MEMD (2013) Rural electrification strategy and plan 2013-2022. Kampala, The Government of the Republic of Uganda

MEMD (2014) 2014 Statistical abstract

MEMD (2016) National Charcoal Survey for Uganda 2015. Kampala

Miller RL, Ulfstjerne MA (2020) Trees, tensions, and transactional communities: problematizing frameworks for energy poverty 
alleviation in the Rhino Camp refugee settlement Uganda. Energy Res Soc Sci. https://doi.org/10.1016/j.erss.2019.101404

Müller F, Claar S, Neumann M, Elsner C (2020) Is green a PanAfrican colour? Mapping African renewable energy policies and transitions in 34 countries. Energy Res Soc Sci 68:101551. https://doi.org/10.1016/j.erss.2020.101551

Munro PG, Bartlett A (2019) Energy bricolage in Northern Uganda: rethinking energy geographies in Sub-Saharan Africa. Energy Res Soc Sci 55:71-81. https://doi.org/10.1016/j.erss.2019.04.016

Musinguzi WB, Okure MAE, Wang L et al (2012) Thermal characterization of Uganda's Acacia hockii, Combretum molle, Eucalyptus grandis and Terminalia glaucescens for gasification. Biomass Bioenerg 46:402-408. https://doi.org/10.1016/j.biom bioe.2012.08.001

MWE (2017) State of Uganda's forestry 2016

MWLE (1992) National biomass study , phase I, 1989-1991. Kampala

MWLE (2002) National biomass study technical report of 1996-2002. Kampala

National Forestry Authority (2009) National biomass study, technical report 2005. Kampala

Orwa C, Mutua A, Kindt R, Simons A (2009) Agroforestree database:a tree reference and selection guide version 4.0. In: Agroforestree database. http://www.worldagroforestry.org/af/ treedb/

QGIS Development Team (2015) QGIS Geographic information system. Open Source Geospatial Found. Proj

R Development Core Team (2016) R software. R: a language and environment for statistical computing

Tabuti JRS, Dhillion SS, Lye KA (2003) Firewood use in Bulamogi County, Uganda: species selection, harvesting and consumption patterns. Biomass Bioenerg 25:581-596. https://doi.org/10.1016/ S0961-9534(03)00052-7

UBOS (2017a) Statistical abstract 2017. Kampala

UBOS (2017b) Uganda National Household Survey 2016/17. Uganda Natl Househ Surv 272

UBOS (2019) Statistical abstract 2019. Uganda Bur Stat -Stat Abstr 384

Ugalde L, Pérez O, Mead DJ (2001) Mean annual volume increment of selected industrial forest plantation species. Rom

UNDP (2000) World energy assessement: energy and the challenge of sustainablitiy

UNHCR (2016) Multi-year pilots promoting solutions in Ghana, Senegal, Tanzania, Uganda, Costa Rica and Ecuador 2016-2019

United Nations (2015) Transforming our world: the 2030 agenda for sustainable development-resolution adopted by the General Assembly on 25 September 2015, Seventieth session, A/RES/ $70 / 1$

URRP (2020) Refugees and Nationals per Distric. https://ugandar efugees.org/. Accessed 28 Jul 2020

Van Der Kroon B, Brouwer R, Van Beukering PJH (2013) The energy ladder: theoretical myth or empirical truth? Results from a metaanalysis. Renew Sustain Energy Rev 20:504-513. https://doi.org/ 10.1016/j.rser.2012.11.045

Wickham H (2016) ggplot2: Elegant graphics for data analysis

Wickham H (2017) tidyverse: easily install and load the "tidyverse"

Yu-Ting Lee L (2013) Household energy mix in Uganda. Energy Econ 39:252-261

Publisher's Note Springer Nature remains neutral with regard to jurisdictional claims in published maps and institutional affiliations. 